\title{
Leapfrogging potential for sustainable energy transition in Serbia
}

\section{Hakala, Emma Sofia}

2016-09-13

Hakala , E S \& Batas Bjelic , I 2016 , ' Leapfrogging potential for sustainable energy transition in Serbia ' , International Journal of Energy Sector Management, vol. 10 , no. 3 , pp. 381-401 . https://doi.org/10.1108/IJESM-12-2014-0001

http://hdl.handle.net/10138/297757

https://doi.org/10.1108/IJESM-12-2014-0001

acceptedVersion

Downloaded from Helda, University of Helsinki institutional repository.

This is an electronic reprint of the original article.

This reprint may differ from the original in pagination and typographic detail.

Please cite the original version. 


\title{
Leapfrogging potential for sustainable energy transition in Serbia
}

Aleksanteri Institute, University of Helsinki, Helsinki, Finland, and

Ilija Batas Bjelic

Department of Power Engineering, Faculty of Electrical Engineering, University of Belgrade, Belgrade, Serbia

\begin{abstract}
Purpose - This paper aims to look at the dilemma of promoting sustainable energy transition in post-socialist countries while containing social and economic implications, focusing on the case of Serbia. The aim is to analyse Serbian energy status taking into account historical factors, to analyse barriers that are hindering transition and to identify leapfrogging potential for the sustainable energy development of the country.
\end{abstract}

Design/methodology/approach - Energy transition and leapfrogging potential have been qualified and quantified by indicators, our own calculations and policy analysis to identify barriers to sustainable energy.

Findings - The country has vast potential for leapfrogging in energy transition, yet continues the gradualist approach based on several policy barriers to the process. The analysis shows six barriers related to low energy price, high energy intensity, prioritization of energy security, inadequacy of utilization of renewable sources, lack of policy coherence and dependency on external funding. However, these barriers could be overcome with an energy policy emphasizing leapfrogging potential. As is pointed out in the conclusion, this should be based on the difference between EU-28 average indicators, discrepancy between use and availability of renewable energy, potential for regional cooperation in the energy sector and under-used skills and participation.

Originality/value - The paper discusses energy transition in its historical context, arguing that it has to be considered as comprehensively with societal implications and effects, thus creating useful knowledge for other post-socialist countries in current and future transitions.

Keywords Energy balance, Optimization, Renewable energies, Energy transformation, Democratization, Leapfrogging, Socio-economic barriers

Paper type Research paper

\section{Introduction}

As climate change has become one of the big issues of our time, calls to contain its impact have become ever more forceful. In particular, there is a need to limit harmful

The first author would like to thank Prof. Veli-Pekka Tynkkynen (University of Helsinki) for his valuable comments given for this paper. The work of the second author research has been a part of the research project "Integrated Energy Networks" no. III 42,009/2011, supported by the Ministry of Education and Science of the Republic of Serbia. Authors are thankful to Mr Mirko Dautović, Jenni J. Laakso and the Roth family for English proof reading of the article.

Sustainable energy transition

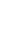


IJESM 10,3 greenhouse gas (GHG) emissions, which contribute to climate change. While international action has remained slow, measures introduced for example within the European Union (EU) have had an effect on national policies and created new incentives for private enterprises. Energy production, as the greatest single source of harmful emissions, is crucial for the efforts. The industry has vast potential to put improved technologies to use and to explore new sources of production that could considerably lower the current emission levels. This, however, requires a transformative change of technology towards sustainable solutions; or sustainability transition, as it has been termed in the scientific literature (Grin et al., 2010).

Although often considered to be lagging behind in energy sector development, post-socialist countries are not resistant to the new challenges. Often they need to or are forced to "catch up" (Balunović, 2014) with even more urgent change, as their energy production is usually characterized by low efficiency and high environmental and social impacts (Buzarovski, 2007; Pavlínek and Pickles, 2004). In light of the new literature, the incomplete post-socialist transition could in fact be considered an asset with regard to the efforts to improve sustainability. By aiming to move directly into the latest generation of sustainable energy sources and technologies - thus "leapfrogging" over some previous stages of development - the ex-socialist countries can benefit from double gains. This is an especially pertinent question in countries suffering from high levels of energy poverty.

The sustainability question is especially pressing for countries in transition, which may be better equipped to benefit from leapfrogging due to higher financial, technological and educational levels than evidenced in developing countries. They are in a unique position to improve their current heavily polluting energy production towards more sustainable models while also dealing with problems of energy poverty similar to those in less developed countries (Fesanghary and Ardehali, 2009). However, leapfrogging requires a clear choice and commitment, particularly in the form of investment into new technologies that are still partly under development (Goldemberg, 1998; Arens et al., 2012). Perhaps because of this, leapfrogging options have so far been poorly explored by transition countries, apart from pointing out that they might be helpful for avoiding known mistakes (Grgurević, 1990). The same also applies to literature on the topic, which is one shortcoming that this article aims to address by exploring the case of Serbia.

Serbia is particularly interesting as it has experienced an exceptionally difficult transition, marked not only by the socialist past but also by recent conflicts in the 1990s (UNEP, 2004). On the other hand, it also has a lot of profitable potential for sustainable development (UNEP, 2013). The aim is to discuss its socialist legacy and transition to market economy and present a contextualized picture of the current status and problems of the Serbian energy sector.

The article will proceed by identifying appropriate sustainable energy indicators on the basis of previous literature. It will then discuss the transition country context and the historical factors affecting Serbia's energy sector development. The sustainable energy indicators as well as policy analysis of key sector documents will be used to identify the barriers that are locking Serbia into a path of large-scale projects that maintain unsustainable production and worsen energy poverty rather than helping the transition towards sustainability. Instead of focusing on merely technological preconditions, the article will provide a perspective into the societal and political incentives and barriers to 
energy transition. Finally, potential on which to base leapfrogging efforts in Serbia will be suggested.

\section{Sustainability and leapfrogging}

The concept of sustainable development became established with the publication of the so-called Brundtland report (or Our Common Future) in 1987. In the definition of the report, which also is adopted in this article, sustainable development "meets the needs of the present without compromising the ability of the future generations to meet their own needs" (Bruntland, 1987, p. 5) while taking into account the environmental, social and economic consequences of human actions (Bruntland, 1987, p. 43). Later literature, however, remarks that it may be nearly impossible to coin a single all-encompassing definition (Mawhinney, 2008; Pezzey, 1992). According to Baker et al. (1997), this makes the concept particularly applicable into practice, yet the ambiguity also makes it important to develop indicators for its measurement (Robert et al., 2005).

In energy production, sustainable development has been said to involve three main goals: the energy savings on the demand side, efficiency improvements in production and the replacement of fossil fuels with renewable sources (Lund, 2007, p. 912). Yet, the wider implications go beyond this: energy sector forms an important basis for a functioning economy, provides livelihoods for the society and has considerable environmental impacts (Kaygusuz, 2012; OECD/IEA, 2010).

Sustainable energy is also closely related to energy poverty, usually defined as the inability to "heat the home up to a socially and materially necessitated level" (Buzarovski, 2007, p. 225). In post-socialist countries, it can be a reason for upholding fossil fuel production and subsidizing energy prices (Ürge-Vorsatz and Tirado Herrero, 2012), which in the long-term leads to an intolerable environmental cost (Kaygusuz, 2011; Walz, 2010) and lagging development (Kovačević, 2008). Renewable energy has been proposed as a solution towards sustainable development (Dincer and Acar, 2015; Kaygusuz, 2011), but it should be noted that sustainability also needs to take into account the environmental, social and economic impacts beyond renewability (Bilgen et al. 2004; Silva Lora et al., 2011). The double challenge of improving energy access while also ensuring sustainability has been increasingly acknowledged at the global level, as exemplified e.g. by the UN initiative Sustainable Energy for All (SEE4ALL) started in 2011 (Welsch et al., 2012).

Considering the complex economic, social and environmental linkages of the energy sector, it is clear that it needs to go through transformative changes to achieve sustainability. This kind of a sustainability transition requires the existence of new, improved technological solutions and their diffusion to relevant actors. Transitions may be hindered by existing networks and institutions seeking to retain their standing, which leaves a key role for regulation and governance to mediate between different actors and either compensate or otherwise encourage them. (Jacobsson and Johnson, 2000, p. 633; Markard et al., 2012, p. 956). In addition, sustainability transition requires innovation, which depends on research and financial resources. Governments and regulators can assist also here by providing subsidies and policies, but they should still allow individual choice for private actors on decisions about "optimal" technology (Jacobsson and Johnson, 2000, pp. 633-634).

The transition can be accelerated by the aforementioned leapfrogging. Developing and post-socialist countries could use it to opt for sustainable sources and achieve
Sustainable energy transition 
IJESM

10,3

Western levels of economic growth without having to depend on fossil fuels in the same way (Goldemberg, 1998; Murphy, 2001; Perkins, 2003). Leapfrogging can be particularly beneficial on the local level, as it proposes small-scale projects as an effective solution when the quality of existing energy networks, population densities and funds for investment are low (Murphy 2001, p. 174; Szabó et al., 2013; Zerriffi and Wilson, 2010). This can be helpful in developing the kind of flexibility needed for sustainable energy systems, which are likely to use various technologies and sources rather than depend on only one solution (Jacobsson and Johnson, 2000, pp. 633-634).

\section{Methods}

To carry out the analysis of sustainability and leapfrogging in the energy transition in Serbia, this article relies on quantitative data on sustainable energy indicators, which will be complemented by qualitative policy analysis of key documents.

Any conceptualization of sustainable energy needs to take into account a complex interaction of economic, societal and environmental factors and is therefore best captured through a set of indicators. Several approaches have been taken to come up with these, most prominently by the IAEA (2005), the IEA (OECD/IEA, 2012) and UN Commission for Sustainable Development (UNCSD, 2007). The IAEA set is the most comprehensive, with 30 indicators divided between the social, economic and environmental aspects. IEA focuses on energy access and UNCSD incorporates energy only as one small part of sustainable development. As none of these approaches comply exactly with our objective, which is to examine the sustainable energy status and leapfrogging potential in Serbia, we have compiled a set of the most relevant indicators based on the conditions needed for sustainability transition and leapfrogging, as outlined in Section 2. To get a more dynamic picture, the latest available data from 2012 will be compared to that from 2005 . The year 2005 was chosen as it is the first year after the secession of Montenegro from the Union of Serbia and Montenegro.

The indicators are given in Table I.

While the transition indicators present the current energy sector status, the leapfrogging indicators focus more on potential. Renewable energy production potential

\begin{tabular}{|c|c|c|c|}
\hline Objective & Condition & Indicator & Unit \\
\hline \multirow[t]{5}{*}{$\begin{array}{l}\text { Sustainable energy } \\
\text { transition }\end{array}$} & Current production & $\begin{array}{l}\text { Share of sustainable (renewable) } \\
\text { production in total energy } \\
\text { production }\end{array}$ & $\%$ \\
\hline & Current consumption & $\begin{array}{l}\text { Share of sustainable (renewable) } \\
\text { consumption in total energy } \\
\text { consumption }\end{array}$ & $\%$ \\
\hline & Efficiency & TPES/GDP PPP & TWh \\
\hline & Energy poverty & $\begin{array}{l}\text { Share of total household income } \\
\text { spent on energy }\end{array}$ & toe/000 US $\$_{2005}$ \\
\hline & Environmental impact & $\mathrm{CO} 2 / \mathrm{GDP} P \mathrm{PP}$ & $\%$ \\
\hline \multirow[t]{3}{*}{ Leapfrogging } & Availability & $\begin{array}{l}\text { Total sustainable (renewable) } \\
\text { energy production potential }\end{array}$ & $\mathrm{kgCO}_{2} / \mathrm{US}_{2005}$ \\
\hline & Utilization of potential & $\begin{array}{l}\text { Total amount of renewable } \\
\text { energy production }\end{array}$ & TWh \\
\hline & Competitiveness & Energy price & $\mathrm{c} € / \mathrm{kWh}$ \\
\hline
\end{tabular}

\section{Table I.}

Indicators for sustainable transition and leapfrogging in Serbia 
is taken as an indicator of the availability of resources in Serbia, which is an important factor determining their future utilization. Meanwhile, current energy price for households is an indicator for the competitiveness of sustainable energy on the market: if the price is artificially maintained below actual production cost, it will be more difficult to introduce sustainable sources without heavy subsidies.

However, the quantitative indicators alone cannot reflect the full picture of the energy transition in Serbia. To take into account historical, societal and political developments, policy analysis has also been carried out on the key documents of the Serbian energy sector, that is Energy Law from 2011, Energy Sector Development Strategy for 2005-2015, draft Energy Sector Development Strategy for 2015-2025[1] and the National Renewable Energy Action Plan. The focus is on their inherent and comparative consistency and the practicability of the measures they propose which may present barriers to the leapfrogging. This analysis has been complemented with data on relevant political processes and developments in the energy sector. On the basis of this comprehensive perspective, it is possible to discern the major barriers to sustainable energy in Serbia. However, the analysis also brings to light a number of clear opportunities to use leapfrogging to overcome the current barriers. These are elaborated in the Conclusions section.

\section{The legacy of socialism and conflict in the energy sector in Serbia}

To understand the current energy policies and barriers to development in Serbia, it is necessary to look briefly at the past. The negative effects of previous decisions are reflected in current policy. While measures to correct them will have positive effects in the long run, they tend to have negative ones in the short run. This, in turn, reinforces the need for a comprehensive change such as the one proposed in the sustainability transition theory.

\subsection{Inefficiency of energy production}

One of the central elements of the socialist ideology was industrial production, which also had a programmatic role as the means for "catching up" with the West through massive projects (Pavlínek and Pickles, 2004). Affordable energy provision was the precondition for this effort and a key feature in the socialist society. Technical decision-making was optimized on the basis of artificially low, regulated prices of fuel, energy and materials, so efficiency gains were not valued. The general public also learned to expect energy to be provided to them cheaply as a public good instead of costing the market value (Mitra et al., 2010). The energy sector has usually been perceived as a driver for employment, production and domestic resources (Gereke, 1982; Požar, 1968); an approach neglecting the external social and environmental costs of this development pattern.

In the 1980s, increasing energy consumption, rising national debt and eventually the end of socialism forced Yugoslavia to push for sovereign energy production, which mainly meant lignite (Carter and Turnock, 1996, pp. 179-180). This only intensified during the 1990s, especially in the years of economic embargo (Ljubicic and Bukurov, 1990). The nuclear option of the 1980s was discarded (Afgan, 1987; Požar, 1985), and renewable energy was not used, apart from hydro and biomass (Kukobat, 1998). There was no credit or tax policy to encourage energy efficiency either for industry 
IJESM 10,3

(Mihić, 1991) or for households, which created a "locking in" effect that led to an increase in total energy consumption (Kovačević, 2008).

Apart from contributing to energy poverty and inefficiency, this legacy hinders economic growth and innovation (Kovačević, 2008). The heavy reliance on emission intensive energy sources has considerable environmental impacts, estimated at 1.8-4.9 billion $€$ (Kovačević, 2013), making it difficult to modernize production towards more sustainable patterns (Bouzarovski, 2010; Buzarovski, 2008; Pavlínek and Pickles, 2004). Likewise, the inefficient district heating system, e.g. in Novi Sad, results in high and rising household heating costs compared to countries like Finland (Macura et al., 2014). According to information from the media (Todorović, 2015), this has already led to protests among the public who expect energy costs to remain subsidized. The situation is not sustainable and requires prompt action, such as leapfrogging measures.

\subsection{Inability to use "positive legacies of socialism"}

Recent research has pointed out that socialism may have some positive legacies in the energy sector (Buzarovski, 2008). For example, lignite dependency was not as high in Serbia as in some other socialist countries, and Serbia also used natural gas and hydropower as energy sources (Pavlínek and Pickles, 2004, p. 239; Buzarovski, 2008, pp. 416-417). District heating was favoured especially in cities, meaning that networks and capabilities for its utilization exist, with the possibility of generation from renewable sources (Ürge-Vorsatz et al., 2006, pp. 2280-2284). Meanwhile, the significant role of hydropower remains at 60 per cent (Karakosta and Doukas, 2011) of total energy potential and is important as a source of flexibility for the integration of the more variable energy sources like wind and solar.

Overall, the socialist idea of "catching up" through industrial projects is perhaps not that far from leapfrogging. The difference is one of substance and scale, as sustainable energy projects tend to be small-scale especially compared to the massive and polluting endeavours of the socialist times. Yet, this correlation could prove useful for fostering a new way of thinking and promoting a society-wide energy transition.

\subsection{Lack of cooperation with regional countries}

The legacy of conflict hinders the ability of re-establishing cooperation on energy planning and operation between former Yugoslav countries. Although benefits have been expected (Koritanov and Veselka, 2003) and observed (Kanevce et al., 2013) since the creation of the Energy community in 2005, the promotion of neo-functional integration in the Balkans (Psarras et al., 2011) has not been achieved, resulting in so-called balkanization of energy policy (Szulecki and Westphal, 2014). This causes reduced flexibility and high costs for the maintenance of domestic energy supply (BETTER, 2014). Such problems could be overcome if an efficient energy utility company or market function were able to repeat the coordinated energy management of the former Yugoslavia, rendering wind and solar integration five times easier due to spatial smoothing and complementarities (ćosić et al., 2013).

\subsection{Inadequate infrastructure}

The conflicts of the 1990s and especially the 1999 NATO bombing during the Kosovo conflict hit the Serbian energy sector, leaving oil refineries, transmission systems and other facilities destroyed. Approximated damage to the electricity system is about 240 $\mathrm{M} €$, but additional industrial damage is estimated to be 2,762 M€ (Dinkić, 1999). 
Economic sanctions and trade embargoes also severely harmed foreign trade (Bideleux and Jeffries, 2007, pp. 246-269) and hindered the maintenance of facilities. This further forced Serbia to continue to produce energy from the existing lignite reserves and to use obsolete, inefficient technologies.

Sustainable energy transition

\section{Energy sector transition and current status}

All the problems of Serbian energy policy cannot be pinned down to past choices. After the overthrow of the regime of Slobodan Milosevic in October 2000 (Bideleux and Jeffries, 2007, pp. 243-275), Serbia started an ambitious reform of the energy sector, which was considerably supported by international financial institutions such as the World Bank. However, it has not thoroughly succeeded especially in the area of sustainable development.

Overall, energy reforms have aimed at liberalizing and privatizing markets while simultaneously modernizing production. The industry should be unbundled, and the consumer price of energy raised and energy security be improved (EBRD, 2001), p. 15). However, while it has become increasingly important also to push forward renewable energy targets and energy efficiency (EC, 2012, pp. 42-43), it can be questioned whether the reform goals truly enable the kind of integrated approach needed for sustainable development (Arens et al., 2012). Economic and energy transitions do not necessarily support each other to this end (Todorović and Marić, 2000).

Either way, several crucial steps have been achieved on the transition path:

- New Energy Law in 2004 (***, 2004) and the Energy Strategy (***, 2005), reflecting EBRD transition criteria and EU accession requirements (EBRD, 2001, p. 15; Renner and Trauner, 2009, p. 460);

- establishment of Energy Regulatory Agency and the Transmission System Operator as set in the Energy Law from 2004;

- signing of the Energy Community Treaty (EnC, 2006) that created the South East European Energy Community in 2005, thereby acceding to commitments on further energy sector reforms, including the promotion of renewable energy and local solutions (Mihajlov, 2010);

- decree on feed-in tariffs for electricity produced from renewable energy sources in 2009, (EC, 2013, p. 32), aligned to EU renewables promotion policies (Batas Bjelic and Rajakovic, 2010);

- New Energy Law $(* * *, 2011)$ further detailing the framework for implementing the reforms as by-laws;

- action plan for renewable energy (***, 2012a), with sectoral targets by 2020 and necessary measures for their achievement;

- New Energy Sector Development Strategy for the period until 2025 (***, 2013a) has been changed and adopted by parliament $(* * *, 2015)$ at the end of 2015 ;

- energy and gas market for large consumers was liberalized and market prices introduced in 2013 (EC, 2013, pp. 31-32); and

- energy market for private customers has been liberalized in 2015 with 88 supply licences approved (AERS, 2015), but there is not much interest to switch from public utility company. 
IJESM

10,3
The full picture can be examined by looking at the indicators introduced in Chapter 3 for sustainability transition and leapfrogging, presented in Table II. The indicators reveal characteristics of the Serbian energy sector that either hinder or support sustainability transition. By combining these with policy analysis of the energy sector documents, we have traced a number of barriers to sustainable energy development.

\subsection{Low energy price as a measure to tackle energy poverty}

Currently, Serbian tariffs are recommended by the regulator but must be approved by the government. Such arrangements can distort technical and economic incentives on which tariffs should be based (Mitra et al., 2010). As the energy price indicator shows, there has been an upward trend since 2005. However, this has not been enough to encourage energy efficiency or sustainable consumption and production (EBRD, 2014, pp. 38-39; Lin and Liu, 2012). The price is still fairly low compared for example to the average energy price[2] in the EU-28 in 2012 of $19.5 \mathrm{c} € / \mathrm{kWh}$ (EU-17 of 20.5).

As can be seen from Table II, the low, subsidized energy price has been a way to tackle energy poverty. Although the electricity price has constantly increased from 2005 to 2012, the constant energy poverty indicator, around 10 per cent, indicates regulation of the price according to income level. It is worth noting that this gradualist approach in the regulation of the electricity price, with around 8 per cent annual average price increase, started after the 2003 introduction of a new energy law (***,2004), while for the first two years of transition, the average was around ten times higher (Filipovic et al., 2012). Taking into account the regulation of electricity, gas and district heating prices (are not shown in Table II), it is reasonable to assume that biomass price, as the only non-regulated fuel price, will be regulated indirectly, especially in weak market conditions. Thus, regulation continues to discourage energy efficiency and fuel switch alternatives which would make way for leapfrogging (Murphy, 2001).

The question is politically sensitive as vulnerable groups of population could be highly affected by any price rise. The share of household income spent on energy has been about 9 per cent from 2005 to 2015, which is high in comparison to, for example, for UK (4 per cent), Portugal ( 6 per cent) or Spain ( 6 per cent) according to data from the blog Carbonbrief (Webster, 2014). In 2013, the government adopted a Decree on the Protection of Vulnerable Customers, which included measures to tackle energy poverty. However, the policy is still based on providing customers with cheap fossil-based energy, keeping the consumption high and also discouraging energy efficiency and fuel switch (Macura et al., 2014). Although the regulation of energy prices can keep energy bills below desired percentage of the income, it is not likely to be sustainable in the long run and does not encourage leapfrogging into new market-based innovations. It seems, therefore, that state institutions in Serbia have in some cases effectively become actors hindering transition, similarly to the manner suggested by (Jacobsson and Johnson, 2000, p. 633).

\subsection{Lack of attention to high energy intensity}

As Table II shows, energy consumption per GDP has been slowly decreasing, but is still far higher than for example the $0.18 \mathrm{TPES} / \mathrm{GDP}$ of the neighbouring Croatia (IEA, 2012). The Serbian economy was already highly energy intensive in the 1990s compared to the EU average, which then was already below 0.2 TPES/GDP (IEA, 2014). Although production declined because of conflicts and bombing, consumption shifted from 


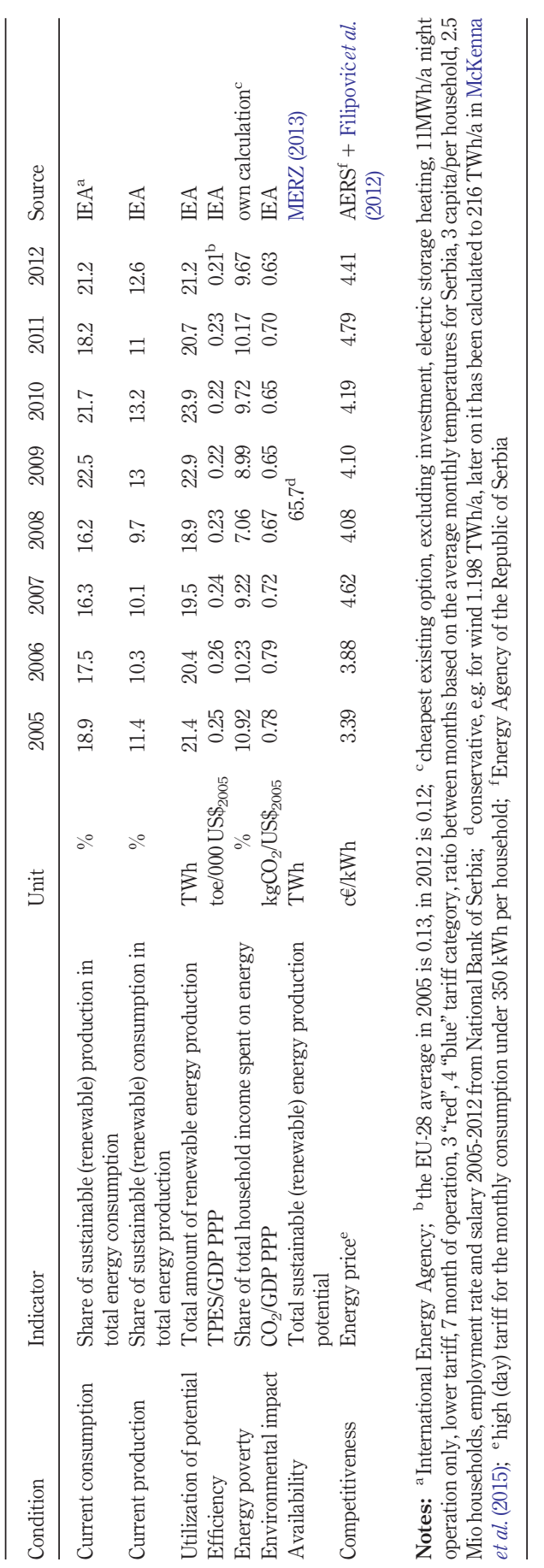

Sustainable energy transition

Table II.

Selection of sustainable energy indicators for the republic of Serbia 
IJESM

10,3

10

industry to households, which further increased energy intensity as the same generation portfolio was used. The current ratio of energy intensity to EU-28 average of 1.74:1 creates potential for improvement through leapfrogging.

Yet, efforts to improve energy efficiency have been ineffective. While the issue is acknowledged in all the energy sector strategies (***, 2005, p. 18; ***, 2012a, p. 3; ***, 2013a, p. 60) and there are also separate energy efficiency plans (***, 2010; ***, 2013b), decisive action or concrete measures are still lacking. In the private and public sectors, awareness about the potential profitable consequences of energy efficiency continues to be low (Bovan and Mamula, 2015). If efficiency projects were more widely explored, they could generate budgetary savings in the Serbian public sector (Petrović Bećirović and Vasić, 2013).

This lack of attention may be particularly severe in terms of missed opportunities for leapfrogging. Energy efficiency has been described as the fastest and cheapest way to improve energy access and cut emissions while also being cost-effective. Yet, it is often not properly taken up by consumers and businesses on their own but needs governmental support and policies (Kaygusuz 2012, p. 1121). By failing to implement these more efficiently, the Serbian government is doing a considerable disservice to the energy sector of the country.

\subsection{Energy security as the overriding post conflict objective}

Qualitative analysis of the policy documents shows that there is a tendency in Serbian energy policy to prioritize energy security above all other goals. Both the previous and new energy strategy focus on securing energy supply through increased large-scale production from domestic fossil sources, as the list of planned priority projects until the year 2020 show (Table III). This has led to a "locking in" effect for sustainability in the energy sector, due to a lack of flexibility and a high technical minimum for electricity production from technologically obsolete fossil fuel plants (Batas Bjelić et al., 2013b).

The planned projects are mainly big thermal power plants on new and existing mines, or alternatively pumped hydropower plants (Table III). Renewable energy projects are primarily seen as an opportunity for foreign and private investors and are only included as projections, not set investments. Although the outline only covers priority projects until year 2020, meaning that there will be a chance to

Table III.

Project list additional to NREAP that could be finished until 2020

\begin{tabular}{llccccl}
\hline Type & Project name & Power [MW] & Efficiency [\%] & Energy [TWh/a] & Mine type & Importance \\
\hline PSHPP & Bistrica & 600 & & 60 & & Strategic \\
PSHPP & Djerdap 3 & 600 & & 14 & & National \\
HPP & Velika Morava & 150 & & 0.645 & & National \\
TPP & TENT B3 & 744 & 40 & 24 & new & Strategic \\
TPP & Kolubara B & 700 & 40 & 20 & existing & National \\
TPP & Kostolac B3 & 350 & 40 & 10 & existing & National \\
TPP & Kovin & 700 & 40 & 11 & new & National \\
TPP & Stavalj & 300 & 40 & 7 & new & Strategic \\
CHP & Novi Sad & 450 & $58 / 22$ & 1 & existing & National \\
Bio fuel & Bio ethanol & & & 2 & & Not known
\end{tabular}

Source: Batas bjeli\&cacute; et al. (2013a, 2013b) 
complement the plans at a later time, the current choices are likely to limit the financial feasibility of sustainable options also in the future. Instead of forward-looking exploration of sustainable options, Serbia is investing on lignite, which, even in the case of modernization of plants, implies a reliance on fossil fuels for a long time to come. Investments on conventional sources, seen to be less financially risky than new technologies, take priority especially in conditions of economic crisis.

In the long term, however, the security of fossil fuels is questionable. This was already demonstrated during the 1999 Kosovo conflict, as well as the 2008 declaration of independence of Kosovo[3], which significantly altered Serbian energy perspectives. The lignite reserves in Kosovo[3] could no longer be seen as a guarantee of secure long-term energy policy. Fossil fuel facilities also experienced severe problems during the Southeast European floods 2014.

However, fossil fuels are not likely to be a sustainable solution to energy security even regardless of external shocks. Not only are their sources being depleted (Arens et al., 2012, p. 21) but also the prevention of climate change has been said to require de-carbonization (OECD/IEA, 2010). Rather than basing their energy sector strategies on fossil sources, countries should instead adapt their energy security policies to promote measures like energy efficiency and increase their share of renewable energy consumption (Kaygusuz, 2012, p. 1118).

Yet, Serbia is moving in the opposite direction. Current energy policy will not help with reaching the goals of increasing energy efficiency and decreasing CO2 emissions (Batas Bjelić et al., 2013a). Table II shows that TPS/GDP PPP, indicating energy intensity, as well as CO2 emissions have both slowly decreased from 2005, but this improvement cannot necessarily be attributed to current policy. In addition, the planned strategy does not take into account that global and EU requirements to cut emissions are only likely to become more strenuous as the fight against climate change intensifies. Furthermore, policies like prioritizing independent energy security apart from common EU policy or producing fossil fuel energy and selling it on the EU market are hard to justify for a candidate country (Batas-Bjelic et al., 2015). Already the recent Energy Union initiative and Memorandum of Understanding (EC, 2014) on a joint approach from the European Commission (Šefčovič, 2015), as well as the reported signing of the Energy Charter Treaty (BETA, 2015) call for further diversification of energy supply and increased solidarity among member and candidate countries. In the worst case scenario, Serbia may eventually have no choice but to belatedly opt for sustainable energy, rendering the present fossil fuel investments obsolete.

\subsection{Inadequate utilization of new sustainable energy sources}

As the indicators show, both sustainable energy production and consumption have slowly increased (Table II). However, this can be mainly attributed to yearly fluctuations of hydro potential and differences between normal, dry and wet conditions. The planned policy expects Serbia to increase the share of renewable energy sources in gross final energy consumption from 21.2 to 27 per cent in 2020, or even to 31.1 per cent in an energy efficient scenario (Batas Bjelić et al., 2013a). However, at the current growth rate, this target is not likely to be achieved (Veum et al., 2015). The technical potential of renewable er production would enable sustainable energy production to be

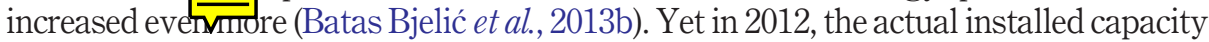

Sustainable energy transition 
IJESM

10,3

12

of renewable energy still remained a minimal fraction of the potential (Table III). The government is not doing all it could to support the transition. For example, the adoption of all by-laws required for the implementation of the incentives system to renewables has been done with low feed-in quotas and without budgetary support or guarantees as in the case of fossil fuel technologies (Table IV).

The choice of those sustainable energy options that are pursued also raises some questions. All the RES capacities proposed in the priority projects (***,2012b) are based on hydropower. In the view of many NGOs and international organizations, large-scale hydropower is not seen as a sustainable energy source because it has negative ecological and social impacts (SEEBankwatch, 2013, p. 26). Also, hydropower has historically been an important source in Serbia, so the construction of new hydropower plants does not enhance local sustainable energy planning skills, which would be urgently needed for leapfrogging (Bazilian et al., 2012).

Meanwhile, natural gas is seen as a driving force of sustainability and a bridge solution to sustainable energy system (***, 2013a, p. 47). While it produces lower GHG emissions than lignite, especially in combined cycle cogeneration facilities, it is still a non-renewable fossil fuel with significant emissions and environmental groups have seen it as another factor delaying the move towards sustainable energy (SEEBankwatch, 2013, p. 23).

These strategic choices apparently fail to take into account that the cost of renewable energy production has generally declined during the past years and that RES options can particularly enable local low-cost solutions (Kaygusuz, 2012, pp. 1122-1123). These advantages are hindered by barriers created by subsidies and price distortions (Bhattacharyya, 2007, p. 27) - as the Serbian case also shows. By not addressing this issue, the government risks ending up wasting all of its efforts to promote renewables.

\subsection{Lack of policy coherence and consistency}

In its introduction, the draft Energy Sector Development Strategy puts strong emphasis on sustainability and the environmental as well as social impacts of the energy sector which are included within the three strategic priorities of the development of the sector in Serbia. However, an explicit definition of sustainability is not given. (***, 2013a, pp. 6-7). In addition, "clean coal", which is presented as one of the means with which to achieve sustainability, is not defined, despite being an inherently controversial term. Furthermore, many of the actions proposed in $\operatorname{NREAP}(* * *, 2012 \mathrm{a})$ are not reflected in the outline of priority projects of the Energy Sector Development Strategy. In fact, the overall Strategy makes little mention of the measures suggested in NREAP, such as the establishment of a market for

\begin{tabular}{lrrrr}
\hline & Biomass & Solar PV & Wind & Small hydro \\
\hline Installed renewable electricity capacity in 2012 & & & & \\
[MW] & 0 & 2.2 & 0 & 31.3 \\
Technical potential for renewable energy & 5,400 & 1,000 & 400 & 4,500 \\
capacity [MW] & 0 & 0.22 & 0 & 0.69 \\
Realization percentage [\%] & & & & \\
Source: UNDP (2013) & & & &
\end{tabular}

Table IV.

Potentials and realization

Source. UNDP(2013)

T4,AQ:2

AQ: 3 
biomass or systematic project planning in the field of renewables (***, 2013a). Overall, this lack of coherence is likely to hinder development on all of the indicators for sustainability transition and leapfrogging.

There also is a lack of balance between market transition and societal objectives. Structural changes necessary to improve the energy efficiency of existing workforce-intensive industries are likely to lead to unemployment and other serious social issues (EC, 2001). This is already evident in the industrial municipalities of Obrenovac, Smederevo and Bor.

In addition, the policy plans are not adequately coupled with financial incentives. Instead, it relies heavily on foreign financing, explained by the lack of domestic sources of finance (Reiche, 2006). This may, however, be based on overly optimistic expectations, considering that such ventures have not been particularly successful in the past. In addition, the visions of foreign investors and Serbian officials do not necessarily fully coincide. For instance, according to media sources, the Luxembourg-based investor Securum Equity Partners and Associates withdrew in 2013 from a $1 \mathrm{GW}$ solar energy project and sued the Serbian government, claiming it had violated their agreement by failing to provide an appropriate site for the facility (Bayar, 2013). Therefore, dependency on foreign funding implies a higher risk that the projects envisioned in the current strategy will not actually be realized.

Another important outside influence is the EU, which has been seen as an exporter of laws (Reiche, 2006) but also is a donor aiming to compensate for the lack of economic development. This influence may have been strategically overestimated in Serbia, leading to an excessive reliance on EU funds to finance sustainable energy. Conversely, the energy strategy documents seem to be aimed at demonstrating the ability of Serbia to meet all the requirements for joining the EU, potentially at the cost of presenting actual trends of energy sector development. Therefore, efforts to tackle the question of sustainable energy transition locally and with a Serbian budget have been neglected.

The literature on sustainability transition in the energy sector very strongly suggests that government support is needed to aid the transition, especially in the case of leapfrogging (Jacobsson and Johnson, 2000; Kaygusuz, 2012). Serbia has unarguably taken the first steps by preparing several crucial strategies and action plans, but these should be followed through with implementation and, in particular, financial incentives to be effective. However, even these measures are easily undermined by the lack of a bigger, strategic commitment at the national level, and the tendency to opt for the gradualist approach in large-scale projects.

\subsection{Lack of public participation in energy sector planning}

Finally, the Serbian sustainable energy policy has not succeeded at engaging public participation in preparing projects (Fleiter et al., 2012). Although the country is a signatory to the Aarhus Convention on Access to Information, Public Participation in Decision-making and Access to Justice in Environmental Matters, and public hearings have been organized for example on the Energy Sector Development Strategy, the policy documents do not demonstrate a consistent effort to implement measures in cooperation with the public. According to the theory, however, increased public participation is a pre-condition for sustainability transition (Bhattacharyya, 2007, p. 29).

Public awareness on sustainable energy is low, weakening the position of the grassroots in relevant decision-making. This may also be one reason for the lack of interest in private sector projects (Bovan and Mamula, 2015). However, the lack of
Sustainable energy transition 
IJESM

10,3

awareness is not just a question for the general public but also concerns all levels of administration. This may be reflected in the low level of publicly funded sustainable energy projects: if the potential benefits of sustainable energy sources are not known to public officials, they are not likely to do a great deal to encourage their development.

Further still, the weak level of awareness gives a relatively free hand to the fossil fuel industry, which has a considerable political and economic power in Serbia (SEEBankwatch 2013). This may further alienate the general public from decision-making in the energy sector and make entry to the market seem too difficult for small-scale actors. Renewable projects, on the other hand, tend to work best on the small scale (Kaygusuz, 2012, p. 1124; Bhattacharyya, 2007, p. 30). Although this does not automatically imply a better incorporation of public participation (Murphy, 2001), the localized character of renewable energy production may make both impacts and benefits more tangible and thus easier to take into account. Thus, the transition may also reinforce participation once it gets underway.

\section{Conclusions: potential for leapfrogging to energy transition}

As has been shown in this article, barriers to leapfrogging to energy transition in Serbia are multi-sectoral yet overlapping and inter-related. However, the analysis also reveals that in the background, there are several points that constitute evident potential for leapfrogging. In the following sub-sections, we point these out in more detail and suggest how they could be used as the basis of a comprehensive approach to leapfrogging linked to general societal development.

\subsection{Difference in sustainable energy indicators between EU-28 average (1.75:1)}

The preceding analysis reveals an adverse gap in the relevant sustainable energy indicators in Serbia when compared to the EU-28 average. While this is unfavourable at the moment, it also implies a remarkable opportunity. Simply by adopting some of the most advanced sustainable energy technologies used in appropriate contexts in EU countries, Serbia could leap several stages in the area of energy transition. In the best possible scenario, this would contribute to domestic technological development and knowledge base, allowing Serbia to become a trailblazer in the energy sector. However, the current strategy with an emphasis on large, slow, fossil-based projects is not likely to achieve this. Small-scale initiatives, on the other hand, are more flexible, fast and affordable, which would enable more room for innovation and risk-taking.

\subsection{Discrepancy between use and availability of renewable energy sources (1:3)}

There also is a clear under-utilization of the renewable energy potential available within Serbia. The country has relatively vast renewable resources available, particularly in biomass and water. Yet, as the article has shown, only hydropower is used to any notable degree due to barriers such as distorted energy prices, an energy security strategy based on fossil sources, and a lack of policy support and financial incentives. Some of the barriers are easier to overcome than others; however, they are closely inter-connected, making it difficult to deal with them individually. Here, it is particularly important that Serbia implement a coherent, comprehensive policy. Ideally, these could especially target the local level and small-scale projects, which have previously been neglected. Locally owned energy solutions could also alleviate the problem of energy poverty, as the social and economic benefits from production could be allocated to the whole community. 


\subsection{Significant potential for regional cooperation in planning and operation in the new} energy security situation

A significant feature that comes up particularly in the historical analysis is the lack of regional cooperation between the Balkan countries. This clearly constitutes a missed opportunity, not only for Serbia but also for the whole region. Although leapfrogging emphasizes the local level, a common regional approach would provide additional benefits, e.g. through a joint energy utility company that could work more efficiently than individual domestic ones. This could also be beneficial for the energy security of the regional countries by providing an additional source of imports for example during critical hours of less predictable weather patterns and hourly availability of renewable energy, or during catastrophic events like floods, thus reducing the long-term dependency on domestic fossil fuel sources.

\subsection{Existing but under-used participation, skills and knowledge}

Sustainable energy development requires specific education and research, but Serbia is relatively well positioned in this sense. It has an educated workforce and an existing knowledge-base, which is under-used at present. Moreover, increased activity in the field is likely to add to these skills and capacities, further strengthening the potential for innovations and new technologies and thus creating a kind of beneficial circle.

In addition, there is an urgent need to improve the awareness on sustainable energy issues, both among the general public and administrative officials. This should involve the specific target of promoting public participation on energy issues. Overall, no important decisions for investments should pass budget lines without public support, and energy policy should be brought into the mainstream of public discussion. This increased attention could also work to inform the private and municipal sectors about renewable energy production and encourage small-scale projects in the field.

As the Serbian case shows, measures to overcome the barriers to sustainable energy transition need to be comprehensive and forward thinking, ideally using a leapfrogging approach. Their initiation will require political and institutional changes as well as some economic investment, but once underway, they can become self-reinforcing. These findings open space for further research on sustainable energy in transition countries, particularly pointing out the need to understand the societal and institutional barriers to its realization, in addition to exploring the necessary technological solutions.

\section{Notes}

1. The Energy Sector Development Strategy from 2015-2025, after having been discussed in public hearings and accepted by the government, was removed from procedure after the 2015 cancellation of the South Stream pipeline project because its agreement was not aligned with the acquis (EC, 2014). It has since been approved by the Parliament in December 2015. However, at the time of writing this article, the draft version provided the best available illustration of sustainable energy development for analysis.

2. From http://ec.europa.eu/eurostat/statistics-explained/index.php/Energy_price_statistics

3. This designation is without prejudice to positions on status, and is in line with UNSCR 1244 and the ICJ Opinion on the Kosovo declaration of independence. 
IJESM

10,3

\section{References}

*** (2004), "The energy law", 84/04, available at: www.aers.rs/FILES/Zakoni/Zakon \%20o\%20 energetici_84-04.pdf (accessed 19 November 2015).

*** (2005), "The energy sector development strategy of the republic of Serbia by 2015", available at: http://weg.ge/wp-content/uploads/2013/05/Serbia-energy-strategy-2005-2015.pdf (accessed 19 November 2015).

*** (2010), "The first energy efficiency plan of the republic of Serbia for the period available at 2010 to 2012", available at: www.energy-community.org/pls/portal/docs/986181.PDF (accessed 19 November 2015).

*** (2011), “The energy law”, 124/12, available at: www.aers.rs/FILES/Zakoni/Eng/Zakon \%20o \%20energetici_57-11.pdf (accessed 19 November 2015).

*** (2012a), "Draft national renewable energy action plan”, December, available at: www.energycommunity.org/pls/portal/docs/2144185.PDF (accessed 19 November 2015).

*** (2012b), "Priority projects of the Ministry of energy, development and environmental protection in the field of energy".

*** (2013a), "Draft energy sector development strategy of the republic of Serbia for the period 2025 with projections by 2030", available at: www.energy-community.org/pls/portal/docs/2144 185.PDF (accessed 19 November 2015).

*** (2013b), "The second energy efficiency plan of Serbia (in Serbian)", Belgrade, available at: www.energy-community.org/portal/page/portal/0633975ADBBB7B9CE053C92FA8C0 6338. (accessed 19 November 2015).

*** (2015), "Draft energy sector development strategy of the republic of Serbia for the period 2025 with projections by 2030 (in Serbian)", available at: www.parlament.rs/akti/ostala-akta/ akta-u-proceduri/akta-u-proceduri.1043.html (accessed 19 November 2015).

AERS (2015), "License register - active licenses", available at: www.aers.rs/Index.asp?1=2\&a= 535\&ed=5\&id_ed=30\&sid=1\&start $=2 \& t p=$ Zanpra (accessed 19 November 2015).

Afgan, N. (1987), Strategy Development of Nuclear Fuel Cycle Technologies for Nuclear Energy Program in Yugoslavia, ETAN, Bled.

Arens, M., Worrell, E. and Schleich, J. (2012), "Energy intensity development of the German iron and steel industry between 1991 and 2007", Energy, Vol. 45 No. 1, pp. 786-797.

Baker, S. (1997), The Politics of Sustainable Development: Theory, Policy and Practice Within the European Union, Routledge, New York, NY, pp. 1-40.

Balunović, F. (2014), Beleške sa slobode, Mediterran publishing, Novi Sad.

Batas Bjelić, I., Rajaković, N., ćosić, B. and Duić, N. (2013a), "Feasibility of Serbian energy policy in reaching EU 2020 goals", Paper presented at the SDEWES, Dubrovnik.

Batas Bjelić, I., Rajaković, N., Ćosić, B. and Duić, N. (2013b), "Increasing wind power penetration into the existing Serbian energy system", Energy, Vol. 57 No. 1, pp. 30-37.

Batas-Bjelic, I., Rajakovic, N., Cosic, B. and Duic, N. (2015), “A realistic EU vision of a lignite-based energy system in transition: case study of Serbia”, Thermal Science, Vol. 19 No. 2, pp. 371-382.

Bayar, T. (2013), "Serbian "OneGiga” solar power project cancelled; Lawsuit threatened", available at: www.renewableenergyworld.com/rea/news/article/2013/08/serbian-onegigasolar-power-project-cancelled-lawsuit-threatened (accessed 19 November 2015).

Bazilian, M., Rice, A., Rotich, J., Howells, M., DeCarolis, J., Macmillan, S. and Liebreich, M. (2012), "Open source software and crowdsourcing for energy analysis", Energy Policy, Vol. 49 No. 1, pp. 149-153. 
BETA (2015), “Srbija potpisala Međunarodnu energetsku povelju”, 20 May, available at: http:// beta.rs/ekonomija/ekonomija-srbija/3902-srbija-potpisala-medunarodnu-energetskupovelju (accessed 19 November 2015).

BETTER (2014), "Prospects for RES cooperation mechanisms between the Western Balkan countries and the EU", better policy brief on, available at: http://better-project.net/sites/ default/files/BETTER_2nd_PolicyBrief_WB.pdf (accessed 19 November 2015).

Bideleux, R. and Jeffries, I. (2007), The Balkans: A Post-Communist History, Routledge, New York, NY.

Bilgen, S., Kaygusuz, K. and Sari, A. (2004), "Renewable energy for a clean and sustainable future”, Energy Sources, Vol. 26 No. 12, pp. 1119-1129.

Bouzarovski, S. (2010), "Post-socialist energy reforms in critical perspective: entangled boundaries, scales and trajectories of change", European Urban and Regional Studies, Vol. 17 No. 2, pp. 167-182.

Bovan, A. and Mamula, T. (2015), "Energy efficiency as a sustainable management challenge case of Serbia”, MEST Journal, Vol. 2015 No. 3, pp. 195-204.

Bruntland, G. (1987), Our Common Future: The World Commission on Environment and Development, Oxford University Press, Oxford.

Buzarovski, S. (2007), "The 'hidden'geographies of energy poverty in post-socialism: between institutions and households", Geoforum, Vol. 38 No. 2, pp. 224-240.

Buzarovski, S. (2008), "Energy, environment and international financial institutions: the EBRD's activities in the Western Balkans", Geografiska Annaler: Series B, Human Geography, Vol. 90 No. 4, pp. 409-431.

Carter, F.W. and Turnock, D. (1996), Environmental Problems in Eastern Europe, Routledge, New York, NY.

Cosić, B., Maršić, T., Krajačić, G., Markovska, N., Batas Bjelić, I., Gota, D. I. and Duić, N. (2013), "The effect of regionally integrated energy systems on $\mathrm{CO} 2$ emissions reduction and wind integration: the case of South East Europe", 6th International conference on sustainable Energy and Environmental Protection, Maribor.

Dincer, I. and Acar, C. (2015), "A review on clean energy solutions for better sustainability", International Journal of Energy Research, Vol. 39 No. 5, pp. 585-606.

Dinkić, M. (1999), Final Account : Economic Consequences of NATO Bombing: Estimate of the Damage and Finances Required for the Economic Reconstruction of Yugoslavia, Stubovi kulture, Beograd.

EBRD (2001), "Economic transition in central and Eastern Europe, the Baltic states and the CIS: energy in transition”, available at: www.ebrd.com/downloads/research/transition/TR01. pdf (accessed 19 November 2015).

EBRD (2014), "Strategy for Serbia", available at: www.ebrd.com/downloads/country/strategy/ serbia.pdf (accessed 19 November 2015).

EC (2001), "Towards a European strategy for the security of energy supply - GREEN PAPER”, Office for Official Publications of the European Communities: European Commission, available at: http://eur-lex.europa.eu/legal-content/EN/TXT/?uri=URISE RV:127037 (accessed 19 November 2015).

EC (2012), "Serbia progress report”, available at: http://ec.europa.eu/enlargement/pdf/key_ documents/2012/package/sr_rapport_2012_en.pdf (accessed 19 November 2015).

EC (2013), "Serbia progress report”, available at: http://ec.europa.eu/enlargement/pdf/key_ documents/2013/package/sr_rapport_2013.pdf (accessed 19 November 2015). 
IJESM

10,3

EC (2014), "Serbia progress report”, available at: http://ec.europa.eu/enlargement/pdf/key_ documents/2014/20140108-serbia-progress-report_en.pdf (accessed 19 November 2015).

$\mathrm{EnC}$ (2006), "Treaty establishing the energy community", available at: www.energy-community. org/portal/page/portal/ENC_HOME/ENERGY_COMMUNITY/Legal/Treaty (accessed 19 November 2015).

Fesanghary, M. and Ardehali, M.M. (2009), “A novel meta-heuristic optimization methodology for solving various types of economic dispatch problem”, Energy, Vol. 34 No. 6, pp. 757-766.

Filipović, S., Nikolić, I. and Dragutinović, S. (2012), "Electricity price as a factor of the national electric power industry sustainability", Industrija, Vol. 40 No. 4, pp. 153-169.

Fleiter, T., Fehrenbach, D., Worrell, E. and Eichhammer, W. (2012), "Energy efficiency in the German pulp and paper industry - a model-based assessment of saving potentials", Energy, Vol. 40 No. 1, pp. 84-99.

Gereke, Z. (1982), Modeliranje energetike $i$ životne sredine: problemi $i$ metode modeliranja optimalne energetske strukture sa posebnim osvrtom na zaštitu čovekove životne sredine, Privredna štampa, Beograd.

Goldemberg, J. (1998), “Leapfrog energy technologies”, Energy Policy, Vol. 26 No. 10, pp. 729-741.

Grgurević, S. (1990), "Energija, ekologija i privredni rast”, Ekonomika preduzeća, Vol. 38 Nos 5/6, pp. 309-316.

Grin, J., Rotmans, J. and Schot, J. (2010), Transitions to Sustainable Development: New Directions in the Study of Long Term Transformative Change, Routledge, New York, NY.

IAEA (2005), "Energy indicators for sustainable development: guidelines and methodologies", available at: www-pub.iaea.org/MTCD/publications/PDF/Pub1222_web.pdf (accesed 19 November 2015).

Jacobsson, S. and Johnson, A. (2000), "The diffusion of renewable energy technology: an analytical framework and key issues for research", Energy Policy, Vol. 28 No. 9, pp. 625-640.

Kanevce, A., Mishkovski, I. and Kocarev, L. (2013), "Modeling long-term dynamical evolution of Southeast European power transmission system”, Energy, Vol. 57 No. 1, pp. 116-124.

Karakosta, C. and Doukas, H. (2011), "Review and analysis of renewable energy perspectives in Serbia", Journal of Energy and Environment, Vol. 2 No. 1, pp. 71-84.

Kaygusuz, K. (2011), "Energy services and energy poverty for sustainable rural development", Renewable and Sustainable Energy Reviews, Vol. 15 No. 2, pp. 936-947.

Kaygusuz, K. (2012), "Energy for sustainable development: a case of developing countries", Renewable and Sustainable Energy Reviews, Vol. 16 No. 2, pp. 1116-1126.

Koritanov, V. and Veselka, T.D. (2003), "Modeling the regional electricity network in Southeast Europe", Power Engineering Society General Meeting.

Kovačević, A. (2008), Zaglavljeni u prošlost: energija, životna sredina i siromaštvo u Srbiji i Crnoj Gori, Centar za slobodne izvore i demokratiju CeSID, Beograd.

Kovačević, A. (2013), "Accession of Serbia to the European Union - importance of material requirements in the energy sector", Research forum of the European Movement in Serbia, Belgrade.

Kukobat, M. (1998), "Mogućnosti korišćenja novih i obnovljivih izvora energije u SR Jugoslaviji”, Energija, ekonomija, ekologija, Vol. 3 No. 1, pp. 168-170.

Lin, B. and Liu, X. (2012), "Dilemma between economic development and energy conservation: energy rebound effect in China”, Energy, Vol. 45 No. 1, pp. 867-873. 
Ljubicic, B. and Bukurov, Z. (1990), "Coal opportunities in Eastern Europe domestic energy development instead of imported energy", Opportunities in the Synfuels Industry, Proceedings, North Dakota.

Lund, H. (2007), "Renewable energy strategies for sustainable development", Energy, Vol. 32 No. 6, pp. 912-919.

McKenna, R., Hollnaicher, S., von der Leye, P.O. and Fichtner, W. (2015), "Cost-potentials for large onshore wind turbines in Europe", Energy Vol. 83 No. 1, pp. 217-229.

Macura, A., Young, J. and Kalmar, Z. (2014), Energïa na drugi način: studije slučaja - Srbija, Fondacija Heinrich Böll - Regionalna kancelarija za Jugoistočnu Evropu, Beograd.

Markard, J., Raven, R. and Truffer, B. (2012), "Sustainability transitions: an emerging field of research and its prospects", Research Policy, Vol. 41 No. 6, pp. 955-967.

Mawhinney, M. (2008), Sustainable Development: Understanding the Green Debates, John Wiley \& Sons, New York, NY.

MERZ (2013), "Draft energy sector development strategy of the Republic of Serbia for the period 2025 with projections by 2030 ", available at: www.energy-community.org/pls/portal/docs/ 2144185.PDF

Mihajlov, A. (2010), "Opportunities and challenges for a sustainable energy policy in SE Europe: SE European energy community treaty", Renewable and Sustainable Energy Reviews, Vol. 14 No. 2, pp. 872-875.

Mihić, S. (1991), “Ne ponavljati greške razvijenih: energija i razvoj”, Direktor, Vol. 23 No. 5, pp. 11-15.

Mitra, P., Selowsky, M. and Zalduendo, J. (2010), Turmoil at Twenty: Recession, Recovery, and Reform in Central and Eastern Europe and the Former Soviet Union, World Bank, Washington, DC.

Murphy, J.T. (2001), "Making the energy transition in rural East Africa: is leapfrogging an alternative?", Technological Forecasting and Social Change, Vol. 68 No. 2, pp. 173-193.

OECD/IEA (2010), "Energy poverty-how to make modern energy access universal", available at: www.se4all.org/wp-content/.../09/Special_Excerpt_of_WEO_2010.pdf (accessed 19 November 2015).

OECD/IEA (2012), "World energy outlook - methodology for energy access analysis", available at: www.worldenergyoutlook.org/media/weowebsite/energymodel/documentation/ energyaccess_methodology_2012_FINAL.pdf (accessed 19 November 2015).

Pavlínek, P. and Pickles, J. (2004), "Environmental pasts/environmental futures in post-socialist Europe”, Environmental Politics, Vol. 13 No. 1, pp. 237-265.

Perkins, R. (2003), "Environmental leapfrogging in developing countries: a critical assessment and reconstruction”, Natural Resources Forum, Vol. 27 No. 1, pp. 177-188.

Petrović Bećirović, S. and Vasić, M. (2013), "Methodology and results of Serbian energy-efficiency refurbishment project", Energy and Buildings, Vol. 62 No. 1, pp. 258-267.

Pezzey, J. (1992), "Sustainable development concepts”, World, Vol. 1 No. 1, p. 45.

Požar, H. (1968), Prilog metodu za određivanje optimalne energetske strukture, Srpska akademija nauka i umetnosti, Odeljenje tehničkih nauka, Beograd.

Požar, Н. (1985), Strategija dugoročnog razvoja energetike Jugoslavije, Македонска академија на науките и уметностите, Скопје.

Psarras, J., Flamos, A., Doukas, H. and Escribano Francés, G. (2011), "Market or geopolitics? The Europeanization of EU's energy corridors", International Journal of Energy Sector Management, Vol. 5 No. 1, pp. 39-59.

Reiche, D. (2006), "Renewable energies in the EU-accession states", Energy Policy, Vol. 34 No. 3, pp. 365-375. 
IJESM 10,3

Renner, S. and Trauner, F. (2009), "Creeping EU membership in South-East Europe: the dynamics of EU rule transfer to the Western Balkans", European Integration, Vol. 31 No. pp. 449-465.

Robert, K.W., Parris, T.M. and Leiserowitz, A.A. (2005), "What is sustainable development? Goals, indicators, values, and practice", Environment: Science and Policy for Sustainable Development, Vol. 47 No. 3, pp. 8-21.

SEEBankwatch. (2013), "Investy in haste, repent at leisure", available at: http://bankwatch.org/ sites/default/files/SEE-IFI-energy.pdf (accessed 19 November 2015).

Silva Lora, E.E., Palacio, E., Rocha, M.H., Grillo Renć, M.L. and Venturini, O.J. (2011), "Issues to consider, existing tools and constraints in biofuels sustainability assessments”, Energy, Vol. 36 No. 4, pp. 2097-2110.

Szabó, S., Bódis, K., Huld, T. and Moner-Girona, M. (2013), "Sustainable energy planning: leapfrogging the energy poverty gap in Africa", Renewable and Sustainable Energy Reviews, Vol. 28 No. 1, pp. 500-509.

Szulecki, K. and Westphal, K. (2014), "The Cardinal sins of European energy policy: nongovernance in an uncertain global landscape”, Global Policy, Vol. 5 No. 1, pp. 38-51.

Todorović, M.R. and Marić, A. (2000), "Energetika u zemljama u tranziciji", Energija, ekonomija, ekologija, Vol. 5 Nos 1/2, pp. 50-55.

Todorović, T. (2015), "Nišlije protestovale ispred toplane”, Politika Online, 7 July, available at: www.politika.rs/rubrike/Srbija/Nislije-protestovale-ispred-toplane.lthtml (accessed 19 November 2015).

UNCSD (2007), Indicators of Sustainable Development: Guidelines and Methodologies, United Nations, New York, NY.

UNDP (2013), "Renewable energy snapshot 2013”, available at: www.eurasia.undp.org/content/ dam/rbec/docs/Serbia.pdf

UNEP (2013), “Green economy scoping study: Serbia”, available at: www.unep.org/greeneconomy/P ortals/88/Research\%20Products/Serbia_GESS.pdf (accesed 19 November 2015).

Urge-Vorsatz, D. and Tirado Herrero, S. (2012), "Building synergies between climate change mitigation and energy poverty alleviation”, Energy Policy, Vol. 49 No. 1, pp. 83-90.

Urge-Vorsatz, D., Miladinova, G. and Paizs, L. (2006), "Energy in transition: from the iron curtain to the European Union”, Energy Policy, Vol. 34 No. 15, pp. 2279-2297.

Veum, K., Uslu, A., Beurskens, L., Tuerk, A., Frieden, D., Symeonides, M.T. and Zehetner, C. (2015), "Assessment of renewable energy action plan implementation and progress of renewable energy in energy community", available at: www.energy-community.org/portal/ page/portal/229DEF054B006737E053C92FA8C0693D (accessed 19 November 2015).

Walz, R. (2010), “Competences for green development and leapfrogging in newly industrializing countries", International Economics and Economic Policy, Vol. 7 Nos 2/3, pp. 245-265.

Webster, R. (2014), "How the cost of energy in the UK compares to other European countries, in five graphs", CarbonBrief, 30 January, available at: www.carbonbrief.org/blog/201 4/01/how-the-cost-of-energy-in-the-uk-compares-to-other-european-countries,-in-fivegraphs/ (accessed 19 November 2015).

Welsch, M., Howells, M., Bazilian, M., DeCarolis, J.F., Hermann, S. and Rogner, H.H. (2012), "Modelling elements of smart grids - enhancing the OSeMOSYS (Open Source Energy Modelling System) code", Energy, Vol. 46 No. 1, pp. 337-350.

Zerriffi, H. and Wilson, E. (2010), "Leapfrogging over development? Promoting rural renewables for climate change mitigation”, Energy Policy, Vol. 38 No. 4, pp. 1689-1700. 


\section{About the authors}

Emma Sofia Hakala, MSoc Sci, is a PhD Candidate in political history at the University of Helsinki, working on a dissertation on the securitization of the environment and the involvement of international organizations in the post-conflict Western Balkans. Emma Sofia Hakala is the corresponding author and can be contacted at: emma.hakala@helsinki.fi

Ilija Batas Bjelic gained Dipl.-Ing diploma from the University of Belgrade in 2008. From 2009 to 2010, Mr Batas Bjelic worked at the Institute of Physics in Zemun, as a Junior Research Engineer. Since 2011, Mr Batas Bjelic has been working as a Reasearch Assistant at the Department of Power Systems, within the School of Electrical Engineering, which is part of the University of Belgrade in Serbia. In 2009, Mr Batas Bjelic performed research in Germany at the Dortmund Technical University and at the Fraunhofer Institute for Systems and Innovation Research, based in Karlsruhe, in 2012, and was awarded a research grant from DAAD.

For instructions on how to order reprints of this article, please visit our website: www.emeraldgrouppublishing.com/licensing/reprints.htm Or contact us for further details: permissions@emeraldinsight.com 


\section{AUTHOR QUERIES}

\section{AUTHOR PLEASE ANSWER ALL QUERIES}

AQau-Please confirm the given-names and surnames are identified properly by the colours.

= Given-Name, $\mathbf{a}=$ Surname

The colours are for proofing purposes only. The colours will not appear online or in print.

AQ1- The following citation is not listed in the reference list. Please provide full details for this citation:UNEP (2004); Batas Bjelic and Rajakovic (2010); IEA (2012); IEA (2014); Šefčovič (2015); Bhattacharyya (2007).

AQ2 - Please provide first column head for Table IV.

AQ3 - Please provide the spelled-out form of the following abbreviation: RES.

AQ4 - Please provide an update for the following reference: *** (2012b).

AQ5- Please provide location for the following reference: Koritanov and Veselka (2003). 